\title{
Angular Cheilitis pada Anak yang Mengalami Defisiensi Nutrisi
}

\author{
Verena M. Ekarisma, Christy N. Mintjelungan, Aurelia S. R. Supit, Johanna A. \\ Khoman
}

\author{
Program Studi Pendidikan Dokter Gigi Fakultas Kedokteran Universitas Sam Ratulangi, \\ Manado, Indonesia \\ Email: verenamila88@gmail.com
}

\begin{abstract}
Nutritional problems in Indonesia and developing countries in general are still dominated by the protein energy malnutrition (PEM) and other micronutrient problems such as iron deficiency and vitamin B complex deficiency. Nutritional deficiency is always accompanied by malnutrition in childhood. Children face the greatest risk of developing malnutrition. This can lead the children to become susceptible to infectious diseases. One of the most common oral infections in children with nutritional deficiencies is angular cheilitis. This study was aimed to review nutritional deficiencies in children with angular cheilitis. This was a literature review study. This study reviewed topics related to nutritional deficiencies in children from previous studies. There were 12 literature reviewed in this study consisting of 11 crosssectional studies and one simple experimental study. The results showed that angular cheilitis was more common in children with malnutrition based on BMI for age measurement and moderate nutritional status based on MUAC measurements. Angular cheilitis type 1 were most commonly found in children with mild nutritional status, while types 2, 3 and 4 were most commonly found in children with moderate nutritional status. None of types 2, 3, and 4 were seen in children with good nutritional status. In conclusion, children with angular cheilitis are mostly deficient in vitamin B complex.
\end{abstract}

Keywords: angular cheilitis, children, nutritional deficiencies

\begin{abstract}
Abstrak: Masalah nutrisi di Indonesia dan di negara berkembang pada umumnya masih didominasi oleh masalah kurang energi dan protein (KEP) serta masalah nutrisi mikro lainnya seperti defisiensi zat besi dan defisiensi vitamin B kompleks. Defisiensi nutrisi selalu dihubungkan dengan kekurangan gizi pada masa anak-anak. Anak-anak menghadapi risiko paling besar untuk mengalami kurang gizi. Defisiensi nutrisi dapat menyebabkan anak rentan terhadap penyakit infeksi. Salah satu penyakit infeksi rongga mulut yang sering terjadi pada anak dengan defisiensi nutrisi ialah angular cheilitis. Penelitian ini bertujuan untuk mengetahui gambaran defisiensi nutrisi pada anak dengan angular cheilitis. Jenis penelitian ialah suatu literature review. Penelitian ini mempelajari topik terkait defisiensi nutrisi pada anak dengan angular cheilitis dari penelitian-penelitian sebelumnya. Pustaka yang diulas dan dipelajari dalam penelitian ini sebanyak 12 pustaka yang terdiri dari 11 studi potong lintang dan satu eksperimental sederhana. Hasil penelitian menunjukkan bahwa lesi angular cheilitis lebih sering ditemukan pada anak dengan status gizi kurang berdasarkan pengukuran IMT/U dan status kurang nutrisi sedang berdasarkan pengukuran LLA. Lesi angular cheilitis tipe 1 paling banyak ditemukan pada anak dengan status kurang nutrisi ringan, sedangkan tipe 2, 3 dan 4 paling banyak ditemukan pada anak dengan status kurang nutrisi sedang dan tidak satu pun lesi tipe 2 , 3, 4 terlihat pada anak dengan status nutrisi baik. Simpulan penelitian ini ialah anak dengan angular cheilitis paling banyak mengalami defisiensi nutrisi mikro vitamin B kompleks.
\end{abstract}

Kata kunci: angular cheilitis, anak, defisiensi nutrisi 


\section{PENDAHULUAN}

Masalah nutrisi di Indonesia dan di negara berkembang pada umumnya, masih didominasi oleh masalah kurang energi dan protein (KEP) serta masalah nutrisi mikro lainnya seperti defisiensi zat besi dan defisiensi vitamin B kompleks. ${ }^{1}$ Keadaan kurang gizi dapat ditemukan pada setiap kelompok masyarakat sebagaimana manifestasi di negara berkembang. Keadaan kurang gizi dapat bersifat endemik dan mengenai hampir separuh dari populasi penduduk negara tersebut. Anak-anak menghadapi risiko paling besar untuk mengalami kurang gizi. ${ }^{2}$

Data UNICEF tahun 2020 melaporkan bahwa jumlah anak yang mengalami kurang gizi secara global mencapai angka 45,4 juta orang dengan prevalensi sebesar 6,7\%, sedangkan anak yang mengalami gizi buruk secara global mencapai angka 13,6 juta orang dengan prevalensi sebesar $2,0 \%{ }^{3}$ Data Kemenkes 2017 menyebutkan anak yang kurus menunjukkan asupan gizi yang rendah. Karena asupan gizi yang rendah, maka anak tidak memiliki daya tahan tubuh (antibodi) yang cukup. Akibatnya, anak menjadi lebih rentan terhadap penyakit infeksi. ${ }^{4}$

Salah satu penyakit infeksi rongga mulut yang rentan terjadi pada anak dengan defisiensi nutrisi ialah angular cheilitis. ${ }^{1}$ Lesi ini sebenarnya dapat disebabkan oleh berbagai macam faktor seperti agen infeksi Candida albicans atau Staphylococcus aureus, faktor mekanis, defisiensi imunitas, dan defisiensi nutrisi. ${ }^{5,6}$ Insidensi angular cheilitis meningkat pada anak, terutama pada anak yang mengalami defisiensi nutrisi, yaitu defisiensi riboflavin, zat besi, asam folat, zinc, pyridoxine, biotin, dan defisiensi protein. ${ }^{7,8}$

Angular cheilitis atau dengan nama lain angular cheilosis, commissural cheilitis, angular stomatitis atau perleche adalah suatu lesi mulut yang ditandai dengan adanya fisura, kemerahan atau deskuamasi pada sudut mulut disertai rasa sakit, kering, rasa terbakar dan terkadang disertai rasa gatal sehingga lesi ini tentunya dapat memengaruhi fungsi dan estetis. ${ }^{9,10}$ Park et al ${ }^{11}$ menyebutkan bahwa penderita angular cheilitis biasanya mengeluhkan rasa sakit, terbakar dan pruritus. Hal ini didukung oleh penelitian yang dilakukan oleh Warnakulasuriya et al ${ }^{12}$ di Srilanka yaitu bahwa 13 dari 49 orang yang menderita angular cheilitis mengeluhkan rasa sakit dan ketidaknyamanan pada sudut mulut saat membuka mulut.

Angular cheilitis adalah salah satu lesi abnormal/patologik yang ditandai dengan adanya fisura pada sudut mulut yang harus diidentifikasi dengan tingkat keterampilan 4. ${ }^{13}$ Peraturan Konsil Kedokteran Indonesia (KKI) tentang standar kompetensi dokter gigi Indonesia khususnya dalam bidang ilmu penyakit mulut menyatakan bahwa dokter gigi diharapkan mampu untuk mengidentifikasi varian abnormal jaringan lunak rongga mulut sehingga dapat dibedakan dengan varian normal berdasarkan pemeriksaan ekstraoral yang dilakukan. Artinya seorang dokter gigi diharapkan mampu untuk melakukan diagnosis terhadap angular cheilitis secara mandiri.

Berdasarkan latar belakang yang telah dipaparkan maka penulis terdorong untuk menelusuri kejadian angular cheilitis pada anak yang mengalami defisiensi nutrisi mengingat masalah nutrisi di Indonesia dan di negara berkembang umumnya didominasi oleh KEP.

\section{METODE PENELITIAN}

Penelitian ini dilakukan selama bulan Mei-Juni 2021 di perpustakaan virtual. Jenis penelitian ialah kualitatif yang merupakan suatu literature review dengan menggunakan pustaka lainnya sebagai objek utama. Populasi dalam penelitian ini ialah seluruh jurnal dan artikel yang diperoleh dari database seperti Google scholar, PubMed, dan ScienceDirect. Kriteria inklusi responden dalam pustaka ialah anak yang berumur 0 bulan-18 tahun, tahun publikasi pustaka Januari 2011-April 2021, serta berbahasa Indonesia dan Inggris. Pustaka yang tidak tersedia full-text dieksklusi dan tidak terhitung sebagai sampel penelitian. 


\section{HASIL PENELITIAN}

Data penelitian ini diperoleh dari Google Scholar, PubMed dan Science Direct. Penulis mendapatkan 12 literatur yang telah melalui proses reduksi data sesuai dengan kriteria inklusi dan analisis yang terdiri dari 11 cross-sectional study dan satu eksperimental sederhana; di antaranya 10 literatur dari Indonesia dan dua literatur dari luar negeri.

Tabel 1 memperlihatkan karakteristik 12 literatur tersebut dengan tahun publikasi berkisar 2011-2021.

Tabel 2 memperlihatkan bahwa berdasarkan status gizi yang diukur menggunakan indeks massa tubuh menurut umur (IMT/U), prevalensi angular cheilitis paling banyak terjadi pada anak dengan status gizi kurang. Pustaka dalam tabel ini juga menunjukkan bahwa lesi angular cheilitis tidak ditemukan pada anak dengan status berisiko gizi lebih, gizi lebih, dan obesitas.

Tabel 3 memperlihatkan bahwa berdasarkan status gizi yang diukur menggunakan indeks lingkar lengan atas, prevalensi angular cheilitis paling banyak terjadi pada anak dengan status kurang nutrisi sedang.

Tabel 4 memperlihatkan bahwa prevalensi angular cheilitis tipe 1 paling banyak terlihat pada anak dengan status kurang nutrisi ringan $(26,6 \%)$, sedangkan tipe 2,3 , dan 4 paling banyak terlihat pada anak dengan status kurang nutrisi sedang dan tidak satupun terlihat pada anak dengan status gizi baik.

Tabel 5 memperlihatkan bahwa anak dengan angular cheilitis paling banyak mengalami defisiensi nutrisi mikro vitamin B kompleks, sedangkan dalam pustaka lainnya oleh Rakhmayanthie ${ }^{14}$ menyatakan adanya lebih dari satu jenis nutrisi yang defisit pada anak dengan angular cheilitis.

Tabel 1. Karakteristik pustaka penelitian

\begin{tabular}{|c|c|c|c|c|c|c|c|}
\hline No & Peneliti & $\begin{array}{c}\text { Lokasi } \\
\text { penelitian }\end{array}$ & $\begin{array}{l}\text { Jumlah } \\
\text { sampel }\end{array}$ & $\begin{array}{l}\text { Jumlah } \\
\text { populasi }\end{array}$ & $\begin{array}{c}\text { Jenis } \\
\text { penelitian }\end{array}$ & Tahun & $\begin{array}{c}\text { Usia } \\
\text { sampel } \\
\text { (tahun) }\end{array}$ \\
\hline 1. & $\begin{array}{c}\text { Rakhmayanthie, } \\
\text { et }^{14} l^{14}\end{array}$ & $\begin{array}{l}\text { Bandung, } \\
\text { Indonesia }\end{array}$ & 53 & 53 & $\begin{array}{c}\text { Cross- } \\
\text { sectional }\end{array}$ & 2013 & $6-18$ \\
\hline 2. & $\begin{array}{l}\text { Hendrijianto, et } \\
\text { al }{ }^{15}\end{array}$ & $\begin{array}{l}\text { Denpasar, } \\
\text { Indonesia }\end{array}$ & 32 & 40 & $\begin{array}{c}\text { Cross- } \\
\text { sectional }\end{array}$ & 2017 & $6-12$ \\
\hline 3. & Alamsyah et al ${ }^{16}$ & $\begin{array}{l}\text { Medan, } \\
\text { Indonesia }\end{array}$ & 174 & 262 & $\begin{array}{c}\text { Cross- } \\
\text { sectional }\end{array}$ & 2014 & $6-12$ \\
\hline 4. & Ilery et al ${ }^{17}$ & $\begin{array}{l}\text { Manado, } \\
\text { Indonesia }\end{array}$ & 112 & 139 & $\begin{array}{l}\text { Cross- } \\
\text { sectional }\end{array}$ & 2012 & $6-12$ \\
\hline 5. & Kristina $^{18}$ & $\begin{array}{l}\text { Medan, } \\
\text { Indonesia }\end{array}$ & 20 & 70 & $\begin{array}{l}\text { Eksperimen- } \\
\text { tal sederhana }\end{array}$ & 2011 & $6-12$ \\
\hline 6. & Purba $^{19}$ & $\begin{array}{l}\text { Medan, } \\
\text { Indonesia }\end{array}$ & 96 & 929 & $\begin{array}{c}\text { Cross- } \\
\text { sectional }\end{array}$ & 2011 & $6-12$ \\
\hline 7. & Hakim $^{20}$ & $\begin{array}{l}\text { Medan, } \\
\text { Indonesia }\end{array}$ & 43 & 43 & $\begin{array}{c}\text { Cross- } \\
\text { sectional }\end{array}$ & 2015 & $6-10$ \\
\hline 8. & Stefanie $^{21}$ & $\begin{array}{l}\text { Tangerang, } \\
\text { Indonesia }\end{array}$ & 163 & 163 & $\begin{array}{c}\text { Cross- } \\
\text { sectional }\end{array}$ & 2015 & $7-9$ \\
\hline 9. & Agung et $\mathrm{al}^{22}$ & $\begin{array}{l}\text { Denpasar, } \\
\text { Indonesia }\end{array}$ & 32 & 40 & $\begin{array}{c}\text { Cross- } \\
\text { sectional }\end{array}$ & 2017 & $6-12$ \\
\hline 10. & Bhalsod et $\mathrm{al}^{23}$ & $\begin{array}{l}\text { Vadodara, } \\
\text { India }\end{array}$ & 511 & 623 & $\begin{array}{c}\text { Cross- } \\
\text { sectional }\end{array}$ & 2019 & $10-14$ \\
\hline 11. & Vyas et $\mathrm{al}^{24}$ & $\begin{array}{l}\text { Dehradun, } \\
\text { India }\end{array}$ & 500 & 789 & $\begin{array}{c}\text { Cross- } \\
\text { sectional }\end{array}$ & 2014 & $0-3$ \\
\hline 12. & Adha $^{25}$ & Medan & 41 & 41 & $\begin{array}{c}\text { Cross- } \\
\text { sectional }\end{array}$ & 2021 & $6-12$ \\
\hline
\end{tabular}


Tabel 2. Gambaran status gizi berdasarkan indeks massa tubuh menurut umur (IMT/U) pada anak dengan angular cheilitis

\begin{tabular}{ccccccccccccccc}
\hline Peneliti & Lokasi & Gizi baik & $\begin{array}{c}\text { Gizi } \\
\text { kurang }\end{array}$ & Gizi buruk & $\begin{array}{c}\text { Beri- } \\
\text { siko } \\
\text { gizi } \\
\text { lebih }\end{array}$ & $\begin{array}{c}\text { Gizi } \\
\text { lebih }\end{array}$ & $\begin{array}{c}\text { Obe- } \\
\text { sitas }\end{array}$ \\
& & $\mathrm{n}$ & $\%$ & $\mathrm{n}$ & $\%$ & $\mathrm{n}$ & $\%$ & $\mathrm{n}$ & $\%$ & $\mathrm{n}$ & $\%$ & $\mathrm{n}$ & $\%$ \\
\hline Hendrijianto $^{15}$ & Denpasar & 4 & 16,6 & 0 & 0 & 20 & 83,3 & 0 & 0 & 0 & 0 & 0 & 0 \\
Alamsyah et al $^{16}$ & Medan & 31 & 47,7 & 25 & 38,4 & 9 & 13,8 & 0 & 0 & 0 & 0 & 0 & 0 \\
Ilery et al $^{17}$ & Manado & 5 & 10,6 & 32 & 68 & 10 & 21,2 & 0 & 0 & 0 & 0 & 0 & 0 \\
Stefanie $^{21}$ & Tangerang & 2 & 15,3 & 7 & 53,8 & 4 & 30,7 & 0 & 0 & 0 & 0 & 0 & 0 \\
Agung et al $^{22}$ & Denpasar & 4 & 16,6 & 20 & 83,3 & 0 & 0 & 0 & 0 & 0 & 0 & 0 & 0 \\
Adha $^{25}$ & Medan & 0 & 0 & 15 & 34,1 & 19 & 48,8 & 0 & 0 & 0 & 0 & 0 & 0 \\
\hline
\end{tabular}

Tabel 3. Gambaran status gizi berdasarkan Lingkar Lengan Atas (LLA) pada anak dengan angular cheilitis

\begin{tabular}{cccccccccc}
\hline Peneliti & Lokasi & \multicolumn{2}{c}{ Gizi baik } & \multicolumn{2}{c}{$\begin{array}{c}\text { Kurang nutrisi } \\
\text { ringan }\end{array}$} & \multicolumn{2}{c}{ Kurang nutrisi } & \multicolumn{2}{c}{$\begin{array}{c}\text { Kurang nutrisi } \\
\text { sedang }\end{array}$} \\
& & $\mathrm{n}$ & $\%$ & $\mathrm{n}$ & $\%$ & $\mathrm{n}$ & $\%$ & $\mathrm{n}$ & $\%$ \\
\hline Kristina $^{18}$ & Medan & 0 & 0 & 20 & 100 & 0 & 0 & 0 & 0 \\
Purba $^{19}$ & Medan & 0 & 0 & 28 & 29,1 & 37 & 38,5 & 31 & 32,3 \\
Hakim $^{20}$ & Medan & 1 & 3,3 & 13 & 43,3 & 16 & 53,3 & 0 & 0 \\
\hline
\end{tabular}

Tabel 4. Gambaran tipe lesi dengan status gizi berdasarkan lingkar lengan atas (LLA) pada anak dengan angular cheilitis

\begin{tabular}{|c|c|c|c|c|c|c|c|c|c|c|}
\hline \multirow[t]{2}{*}{ Peneliti } & \multirow[t]{2}{*}{ Lokasi } & \multirow{2}{*}{$\begin{array}{l}\text { Status Gizi } \\
\quad \text { (LLA) }\end{array}$} & \multicolumn{2}{|c|}{ Tipe 1} & \multicolumn{2}{|c|}{ Tipe 2} & \multicolumn{2}{|c|}{ Tipe 3} & \multicolumn{2}{|c|}{ Tipe 4} \\
\hline & & & $\mathbf{n}$ & $\%$ & $\mathbf{n}$ & $\%$ & $\mathbf{n}$ & $\%$ & $\mathbf{n}$ & $\%$ \\
\hline \multirow[t]{4}{*}{ Hakim $^{20}$} & Medan & Baik & 1 & 3,3 & 0 & 0 & 0 & 0 & 0 & 0 \\
\hline & & $\begin{array}{c}\text { Kurang } \\
\text { nutrisi } \\
\text { ringan }\end{array}$ & 8 & 26,6 & 1 & 3,3 & 3 & 10 & 1 & 3,3 \\
\hline & & $\begin{array}{c}\text { Kurang } \\
\text { nutrisi } \\
\text { sedang }\end{array}$ & 2 & 6,6 & 2 & 6,6 & 4 & 13,3 & 8 & 26,6 \\
\hline & & $\begin{array}{c}\text { Kurang } \\
\text { nutrisi } \\
\text { buruk }\end{array}$ & 0 & 0 & 0 & 0 & 0 & 0 & 0 & 0 \\
\hline
\end{tabular}

Tabel 5. Gambaran jenis nutrisi mikro yang defisit pada anak dengan angular cheilitis

\begin{tabular}{|c|c|c|c|c|c|c|c|c|c|c|c|c|c|}
\hline \multirow[t]{3}{*}{ Peneliti } & \multirow[t]{3}{*}{ Lokasi } & \multicolumn{2}{|c|}{ Zat besi } & \multicolumn{8}{|c|}{ Vitamin B Kompleks } & \multirow{2}{*}{\multicolumn{2}{|c|}{$\begin{array}{l}\text { Asam } \\
\text { folat }\end{array}$}} \\
\hline & & & & \multicolumn{2}{|c|}{ B2 } & \multicolumn{2}{|c|}{ B3 } & \multicolumn{2}{|c|}{ B6 } & \multicolumn{2}{|c|}{ B12 } & & \\
\hline & & $\mathrm{n}$ & $\%$ & $\mathrm{n}$ & $\%$ & $\mathrm{n}$ & $\%$ & $\mathrm{n}$ & $\%$ & $\mathrm{n}$ & $\%$ & $\mathrm{n}$ & $\%$ \\
\hline Bhalsod et $\mathrm{al}^{23}$ & $\begin{array}{l}\text { Vadodara, } \\
\text { India }\end{array}$ & - & - & 21 & 100 & 21 & 100 & 21 & 100 & 21 & 100 & - & - \\
\hline Vyas et $\mathrm{al}^{24}$ & $\begin{array}{l}\text { Dehradun, } \\
\text { India }\end{array}$ & - & - & 32 & 100 & 32 & 100 & 32 & 100 & 32 & 100 & - & - \\
\hline $\begin{array}{l}\text { Rakhmayanthie } \\
\text { et al }^{14}\end{array}$ & Bandung & 23 & 100 & - & - & - & - & - & - & 3 & 13 & 23 & 100 \\
\hline
\end{tabular}




\section{BAHASAN}

Dari 12 literatur yang ditelaah, enam di antaranya menyajikan tabel gambaran status gizi berdasarkan indeks massa tubuh menurut umur (IMT/U) pada anak dengan angular cheilitis, yang berdasarkan data tersebut didapatkan bahwa angular cheilitis paling banyak ditemukan pada anak dengan status gizi kurang. Satu pustaka lainnya mendapatkan hasil yang berbeda dimana prevalensi angular cheilitis paling banyak ditemukan pada anak dengan status gizi baik. Hal ini mungkin disebabkan karena kondisi kesehatan anak yang sudah baik atau sedang dalam proses perbaikan gizi.

Keseluruhan hasil dari Tabel 2 mengindikasikan prevalensi angular cheilitis paling banyak ditemukan pada anak dengan defisiensi nutrisi. Hal ini sejalan dengan penelitian oleh Sriwahyuni et $\mathrm{al}^{26}$ yang mendapatkan bahwa distribusi penderita angular cheilitis berdasarkan status gizi paling banyak ditemukan pada anak dengan status gizi kurang (52\%). Hal ini menunjukkan bahwa anak dengan status gizi kurang akan lebih mudah mengalami angular cheilitis dibandingkan anak dengan status gizi baik.

Status gizi kurang dapat mengindikasikan adanya suatu defisiensi nutrisi khususnya protein, yang mana defisiensi protein merupakan salah satu etiologi dari kejadian angular cheilitis. Gangguan metabolisme protein dan karbohidrat akan mengakibatkan penurunan asam amino dan adenosin trifosfat (ATP) yang kemudian mengakibatkan reparasi dan regenerasi sel terhambat sehingga keutuhan sel epitel berkurang, salah satunya epitel rongga mulut yang rentan terhadap terjadinya infeksi bakteri dan jamur. ${ }^{27}$

Dari 12 literatur yang ditelaah, tiga di antaranya menyajikan tabel gambaran status gizi berdasarkan lingkar lengan atas pada anak dengan angular cheilitis. Berdasarkan data tersebut didapatkan bahwa angular cheilitis paling banyak ditemukan pada anak dengan status kurang nutrisi sedang (dua pustaka) diikuti dengan status kurang nutrisi ringan (satu pustaka). Tingginya prevalensi angular cheilitis pada anak yang mengalami defisiensi nutrisi disebabkan oleh tidak terpenuhinya angka kecukupan gizi (AKG) akibat rendahnya konsumsi energi atau protein dalam makanan sehari-hari. ${ }^{28} \mathrm{Hal}$ ini sejalan dengan penelitian yang dilakukan oleh Dhale et $\mathrm{al}^{29}$ di India yang menunjukkan bahwa berdasarkan pengukuran $\mathrm{BB} / \mathrm{U}$ dan LLA, didapatkan dari 40 anak yang mengalami defisiensi nutrisi terdapat 22 anak $(55 \%)$ menderita angular cheilitis.

Hasil penelitian selanjutnya menunjukkan bahwa prevalensi angular cheilitis tipe 1 paling banyak terjadi pada anak dengan status kurang nutrisi ringan (26,6\%), sedangkan tipe 2, 3, dan 4 paling banyak terjadi pada anak dengan status kurang nutrisi sedang dan tidak satupun tipe lesi 2,3 dan 4 terlihat pada anak dengan status nutrisi baik. Ohman ${ }^{29}$ dalam penelitiannya menyatakan bahwa angular cheilitis dapat ditemukan dalam berbagai bentuk dan dengan tingkat keparahan berbeda-beda; hal tersebut mungkin dapat dikaitkan dengan berbagai etiologi dari angular cheilitis. Dalam kasus ini, Hakim ${ }^{20}$ mengaitkannya dengan defisiensi nutrisi. Namun, hasil ini masih perlu didukung oleh penelitian lain mengenai tipe lesi dan hubungannya dengan defisiensi nutrisi yang dapat dilihat dalam suatu gambaran status gizi.

Hasil penelitian selanjutnya menunjukkan bahwa jenis nutrisi mikro yang paling banyak mengalami defisiensi pada anak dengan angular cheilitis ialah vitamin B kompleks. Hasil ini berbanding lurus dengan penelitian yang dilakukan Batta et $\mathrm{al}^{31}$ di India yang menyatakan bahwa dari berbagai macam defisiensi vitamin, prevalensi defisiensi vitamin B kompleks menunjukkan angka yang paling besar yaitu 153 (18\%). Dari 153 anak tersebut, terdapat 78 anak (50,9\%) yang menderita angular cheilitis.

Hal ini berbeda dengan hasil penelitian Rakhmayanthie $^{32}$ yang menunjukkan bahwa defisiensi vitamin B hanya terlihat pada salah satu jenis saja yaitu vitamin B12. Hal ini terjadi karena Rakhmayanthie ${ }^{32}$ hanya meneliti jenis vitamin B12 (bukan vitamin B kompleks), zat besi dan asam folat. Penelitian Rakhmayanthie juga menunjukkan bahwa anak yang menderita angular 
cheilitis mengalami defisiensi tiga jenis nutrisi. Hal ini sejalan dengan teori bahwa defisiensi satu jenis nutrisi akan berperan pada kejadian defisiensi nutrisi lainnya.

Defisiensi nutrisi seperti defisiensi zat besi, vitamin $\mathrm{B}$, dan asam folat berkaitan dengan angular cheilitis. Keduanya saling berhubungan karena zat besi dan vitamin ialah zat yang esensial untuk mempertahankan sistem imun. Bila tidak tercukupi, sistem imun akan melemah dan mikroorganisme yang awalnya merupakan flora normal seperti Candida albicans dapat berproliferasi dan menyebabkan infeksi. ${ }^{33}$

Hal-hal penting yang dapat dirangkumkan dari bahasan ini ialah berdasarkan status gizi yang diukur menggunakan indeks massa tubuh menurut umur (IMT/U), lesi angular cheilitis paling banyak ditemukan pada anak dengan status gizi kurang. Berdasarkan status gizi yang diukur menggunakan lingkar lengan atas (LLA), lesi angular cheilitis paling banyak ditemukan pada anak dengan status kurang nutrisi sedang. Lesi angular cheilitis tipe 1 paling banyak ditemukan pada anak dengan status kurang nutrisi ringan, sedangkan tipe 2, 3 dan 4 paling banyak ditemukan pada anak dengan status kurang nutrisi sedang dan tidak satu pun lesi tipe 2, 3 dan 4 terlihat pada anak dengan status nutrisi baik.

\section{SIMPULAN}

Anak dengan angular cheilitis paling banyak mengalami defisiensi nutrisi mikro vitamin B kompleks.

\section{Konflik Kepentingan}

Penulis menyatakan tidak terdapat konflik kepentingan dalam studi ini.

\section{DAFTAR PUSTAKA}

1. Ulfa DM. Prevalensi angular cheilitis pada anak SD usia 6-8 tahun di wilayah dataran rendah dan dataran tinggi Kecamatan Tempurejo Kabupaten Jember. Jurnal Fakultas Kedokteran Gigi Universitas Jember; 2013. p. 8. [cited 2021 Mar 28]. Available from: https://repository.unej. ac.id/handle/123456789/1952

2. Surbainingsih S. Hubungan status gizi dengan perkembangan balita usia 4-5 tahun di TK 'Aisyiyah Bustanul Athfal Gendingan' [Naskah Publikasi]. Yogyakarta" STIKES Aisyiyah; 2015.

3. Unicef-WHO-the world bank joint child malnutrition estimates. 2020. [cited 2021 May 8]. Available from: https:// www.who.int/nutgrowthdb/estimates/ en/.

4. Kandala NB, Madungu TP, Emina JBO, Nzita KPD, Cappuccio FP. Malnutrition among children under the age of Five in the Democratic Republic of Congo (DRC): Does geographic location matter? BMC Public Health. 2011;11:261.

5. Lebwohl MG, Heyman WR, Coulson I. Treatment of Skin Disease (4th ed). China: Elsevier Saunders, 2014.

6. Nugraha AP, Mintarsih DK, Adiastuti EP, Soebadi B, Triyono EA, Prasetyo RA et al. Profil angular cheilitis pada penderita HIV/AIDS di UPIPI RSUD Dr. Soetomo Surabaya. Majalah Kedokteran Gigi Indonesia. 2014; 1(1):6.

7. Griffiths C, Barker J, Bleiker T, Chalmers R, Creamer D. Rook's Textbook of Dermatology. UK: John Willey \& Sons Ltd; 2016.

8. Ghom AG, Anil S. Textbook of Oral Medicine (3rd ed). New Delhi: Jaypee Brothers Medical Publisher, 2014.

9. Laskaris G. Color atlas of oral disease in children and adolescents. German: Thieme, 2011; p. 115, 179.

10. Kavcic MK, Skaleric U. Prevalence of oral mucosal lessions in a population in Ljubljana, Slovenia. J Oral Pathol Med. 2000;29(7):331-5.

11. Park KK, Brodell RT, Helms SE. Angular cheilitis, part 1: local etiologies. Cutis. 2011;87(6):289-95.

12. Warnakulasuriya KAAS, Samayaranke LP. Peiris JSM: Angular cheilitis in a group of Srilanka adults: a clinical and microbiologic study. J Oral Pathol Med. 1991; 20(4):172-5.

13. Peraturan Konsil Kedokteran Indonesia Nomor 40 Tahun 2015 tentang Standar Kompetensi Dokter Gigi Indonesia. Jakarta. KKI; 2015. p. 69, 80. [cited 2021 Apr 21]. Available from: http://www.kki.go.id/assets/data/arsip/S alinan_Peraturan_KKI_No_40_Tahun_ 2015.pdf

14. Rakhmayanthie N, Herawati E, Herawati 
DMD. Effect of nutritional intake towards angular cheilitis of orphanage children. Padjajaran Journal of Dentistry. 2016;28(3):170-6.

15. Hendrijanto MS, Dewi IK, Sari NNG. Hubungan status gizi dengan kejadian angular cheilitis pada anak di lokasi tempat pembuangan akhir Suwung Kota Denpasar. Repository Universitas Mahasaraswati Denpasar. 2017. p. $477-$ 81. [cited 2021 April 18]. Available from: http://repository.unmas.ac.id/ journal/detail/4621/hubungan-statusgizi-dengan-kejadian-angular-cheilitispada-anak-di-lokasi-tempatpembuangan-akhir-suwung-kotadenpasar

16. Alamsyah RM, Yanti GN, Pertiwi I. Hubungan status gizi dengan prevalensi angular cheilitis di panti asuhan Sos Childrens Village dan panti asuhan AlJamiatul Wasliyah Medan. Dentika Dental Journal. 2013;17(4):357-61.

17. Ilery C, Mintjelungan CN, Soewantoro J. Hubungan status gizi dengan kejadian angular cheilitis pada anak-anak di lokasi pembuangan akhir Sumompo Kota Manado. e-GiGi. 2013;1(1):32-7.

18. Kristina RH. Perbedaan kecepatan penyembuhan angular cheilitis dengan pemberian vitamin B kompleks dan vitamin B kompleks dalam multivitamin pada anak-anak Panti Asuhan Elida. Repository Universitas Sumatera Utara. 2011. p. 24-5. [cited 2021 April 18]. Available from: https://dokumen.tech/document/ 78582447-perbedaan-kecepatanpenyembuhan-angular-cheilitiskristina-r-h-070600105.html

19. Purba TE. Penyebab defisiensi nutrisi murid penderita angular cheilitis di SD St Antonius dan SD Negeri Padang Bulan Kecamatan Medan Baru. Repository Universitas Sumatera Utara. 2011.p. 28. [cited 2021 April 19]. Available from: https://onesearch.id/Record/IOS3619.1 23456789-30455

20. Hakim LN. Hubungan status gizi dengan insiden keilitis angularis pada anak-anak umur 6-10 tahun di Panti Asuhan Terima Kasih Abadi. Repository Universitas Sumatera Utara. 2015. p. 38-40. [cited 2021 April 19]. Available from: http://text-id.123dok.com/document/ qm011m5y-hubungan-status-gizi- dengan-insiden-keilitis-angularis-padaanak-anak-umur-6-10-tahun-di-pantiasuhan-terima-kasih-abadi-2.html

21. Stefanie CM. Prevalensi cheilitis angularis pada anak dengan defisiensi nutrisi kajian pada anak usia 7 sampai 9 tahun di Sekolah Dasar Negeri 3 Kedaung Wetan, Tangerang. Repository Trisakti. 2014. p. 26. [cited 2021 April 20]. Available from: http://repository. trisakti.ac.id/usaktiana/digital/0000000 0000000082757/2014_TA_KG_04011 027_Halaman-Judul.pdf

22. Agung IGAA, Wedagama AM, Hartini IGAA, Stevani H. Nutritional status and angular cheilitis in school children at Landfill Suwung, Denpasar City. International Journal of Scientific and Research Publications. 2019;9(1):382-5.

23. Bhalsod AS, Dave NN, Thakor N. Prevalence of nutritional deficiencies among school going adolescents of Vadodara, Gujarat, India. Int J Adv Med. 2019;6(6):176770.

24. Vyas S, Kandpal SD, Semwal J, Deepshikha. A study on morbidity profile and associated risk factors in a rural area of Dehradun. Journal of Clinical and Diagnostic Research (JCDR). 2014; 8(8):1-4.

25. Adha TUT. Pengaruh faktor ekonomi dan status gizi buruk terhadap terjadinya angular cheilitis pada anak usia 6-12 tahun. Repositori Universitas Sumatera Utara. 2021. p. 27. [cited 2021 May 7]. Available from: http://repositori.usu.ac. id/handle/123456789/32139

26. Sriwahyuni H, Hernawati S, Mashartini A. Insidensi dan distribusi penderita angular cheilitis pada bulan OktoberDesember tahun 2015 di RSGM Universitas Jember. J Pustaka Kesehat. 2017;5(1):5-12.

27. Dimas I. Prevalensi angular cheilitis pada anak usia 5-18 tahun di Panti Asuhan Habibie Surabaya. Repositori Universitas Airlangga. 2013. [cited 2021 May 7]. Available from: http://repository.unair. ac.id/id/eprint/19558

28. Supariasa N. Penilaian Status Gizi. Jakarta: EGC, 2014.

29. Dhale S, Bhongade M, Susnerwala S. Study of prevalence of various cutaneous manifestations inchildren suffering from severe acute malnutrition (SAM). Jurnal 
of Medical Science and Clinical Research. 2016;4(9):12691-8.

30. Ohman SC, Dahlen G, Moller A, Ohman A. Angular cheilitis: a clinical and microbial study. J Oral Pathol. 1986;15(4): 213-7.

31. Batta M, Gupta N, Goyal G, Jain A. Vitamin deficiency prevalence in primary school children in Punjab, India. Int J Res Med
Sci. 2016;4(12):5176-9.

32. Decker RT, David AS, Connie CM. Nutrition and Oral Medicine. New Jersey: Human Press, 2005.

33. Sjuaibah. Hubungan status gizi dengan terjadinya angular cheilitis pada anak usia 5-12 tahun di lima panti asuhan di Kota Medan. Dentika Dental Journal. 2006;11(2):117-21. 